\title{
PENGGUNAAN MEDIA BONEKA DI KELAS AWAL PADA MADRASAH IBTIDAIYAH
}

\author{
Yayan Carlian ${ }^{1}$, Rika Siti Yulianti ${ }^{1}$ \\ Jurusan Pendidikan Guru Madrasah Ibtidaiyah, UIN Sunan Gunung Djati, Bandung, Indonesia \\ yayan.carlian@uinsgd.ac.id
}

Naskah diterima: 25 Desember, 2017, direvisi: 1 januari, 2018, diterbitkan: 31 Maret, 2018

\begin{abstract}
The research objective of this class action is to determine student learning outcomes before using the media three-dimensional, the use of three-dimensional media, and student learning outcomes by using three-dimensional media on the subject matter of the attitude of harmony and help each other in class III MI Al-Islah. The method used in this research is a classroom action research. The study consisted of III cycles where each cycle consists of planning, action, observation, and reflection. Based on the results obtained can be summarized as follows: 1) student learning outcomes before using a three-dimensional media is still low, with an average value of 70.03 with $46 \%$ mastery learning; 2) the use of three-dimensional media in each cycle has risen in the first cycle of teacher activity 44\%, cycles II 69\%, 81\% the third cycle, shile the activity of the first cycle students $42 \%$, $67 \%$ the second cycle and the third cycle of $67 \%$; 3) the results of student learning outcomes by using the doll media in each cycle has increased. In the first cycle with an average of 73.21 completeness study $54 \%$, then the second cycle with an average of 76.60 completeness study $82 \%$, and the third cycle reach the average grade is 81.43 with $89 \%$ mastery learning.
\end{abstract}

Keywords: morals, learning uutcomes, media dolls, madrasah ibtidaiyah

\begin{abstract}
ABSTRAK
Tujuan penelitian tindakan kelas ini adalah untuk mengetahui hasil belajar siswa sebelum menggunakan media tiga dimensi, proses penggunaan media tiga dimensi, dan hasil belajar siswa dengan menggunakan media tiga dimensi pada materi pokok sikap rukun dan saling tolong menolong di kelas III MI Al-Ishlah. Metode yang digunakan dalam penelitian ini adalah metode penelitian tindakan kelas (PTK). Penelitian ini terdiri dari III siklus dimana setiap siklusnya terdiri dari perencanaan, pelaksanaan tindakan, observasi, dan refleksi. Berdasarkan hasil penelitian yang diperoleh dapat disimpulkan sebagai berikut: 1) hasil belajar siswa sebelum menggunakan media tiga dimensi masih rendah yaitu dengan nilai rata-rata 70,03 dengan ketuntasan belajar 46\%;2) proses penggunaan media tiga dimensi dalam setiap siklusnya mengalami peningkatan yaitu pada aktivitas guru siklus I 44\%, silklus II 69\%, siklus III 81\%, sedangkan aktivitas siswa siklus I 42\%, siklus II $67 \%$ dan siklus III 67\%; 3) hasil belajar dengan mengguankan media boneka pada setiap siklusnya mengalami peningkatan. Pada siklus I dengan rata-rata 73,21 ketuntasan belajar 54\%, kemudian pada siklus II dengan rata-rata 76,60 ketuntasan belajar $82 \%$, dan pada siklus III mencapai rata-rata kelas yang 81,43 dengan ketuntasan belajar $89 \%$.
\end{abstract}

Kata Kunci: moral, hasil belajar siswa, media boneka tangan, madrasah ibtidaiyah

\section{PENDAHULUAN}

Pendidikan merupakan proses yang dilakukan secara sadar dan terencana dalam rangka untuk membantu perkembangan potensi peserta didik guna memiliki kompetensi atau kemampuan yang diharapkan oleh keluarga, masyarakat, bangsa, dan agamanya (Ruswandi, dkk., 2009, hlm. 6). Undang-Undang Nomor 20 Tahun 2003 bab 1 ayat 1 tentang Sistem Pendidikan Nasional menyatakan bahwa: "Pendidikan adalah usaha sadar dan terencana 
untuk mewujudkan suasana belajar dan proses pembelajaran agar peserta didik secara aktif mengembangkan potensi dirinya untuk memiliki kekuatan spiritual keagamaan, pengendalian diri, kepribadian, kecerdasan, akhlak mulia, serta keterampilan yang diperlukan dirinya dan masyarakat". Dari pemaparan di atas penulis dapat menyimpulkan bahwa pendidikan merupakan usaha sadar dan terencana dalam suatu proses pembelajaran dalam rangka untuk membantu perkembangan potensi peserta didik guna memiliki kompetensi-kompetensi atau kemampuan yang diharapkan oleh keluarga, masyarakat, bangsa dan agamanya.

Alat peraga atau media pembelajaran memegang peranan penting sebagai alat bantu untuk menciptakan proses belajar-mengajar yang efektif. Setiap proses belajar mengajar ditandai dengan adanya beberapa unsur antara lain: tujuan, bahan, metode, dan alat, serta evaluasi (Sudjana, 2013, hlm. 99).

Pada umumnya masalah yang dihadapi di Sekolah Dasar atau Madrasah Ibtidaiyah dalam kegiatan pembelajaran adalah berkaitan dengan kurangannya media yang dipergunakan, sehingga jika suatu pembelajaran hanya menggunakan media itu-itu saja minat siswa untuk mengikuti pembelajaran tersebut kurang, karena minat yang kurang maka hasil belajar siswa pun lemah. Seringnya guru dalam melaksanakan pembelajaran menggunakan metode ceramah dan penggunaan media hanya menggunakan buku siswa, sehingga minat siswa terhadap pembelajaran kurang antusias. Padahal jika guru mengetahui bahwa media pembelajaran itu banyak sekali, namun banyak kendala guru untuk menerapkan media tersebut misalnya kendala pada dana dan waktu.

Maka dari itu untuk mengatasi permasalahan di atas maka dalam penelitian ini akan mendesain pembelajaran Akidah Akhlak yang lebih menyenangkan. Penggunaan media atau alat peraga sangat diperlukan untuk meningkatkan hasil belajar siswa. Media yang digunakan untuk mata pelajaran Akidah Aklhak yaitu media tiga dimensi berbentuk boneka. Guru akan mendesain pembelajaran yang lebih menyenangkan melalui media tiga dimensi berbentuk boneka ini. Sebuah artikel mengatakan salah satu kelebihan menggunakan media tiga dimensi boneka ini adalah dapat mengembangkan imajinasi dan minat anak dalam suasana gembira. Selain itu juga dalam sebuah jurnal mengatakan berdasarkan fase perkembangan kognitif yang dikemukakan oleh Piaget bahwa usia 7 sampai 12 tahun anak berada pada periode operasional konkret yaitu anak dapat berpikir logis terhadap benda-benda kongkrit.

Benda kongkrit dalam hal ini adalah boneka. Adapun langkah-langkah penggunaan media tiga dimensi berbentuk boneka sebagai berikut: 1) merumuskan tujuan pengajaran secara jelas, idahului dengan pembuatan naskahnya, 2) lebih banyak mementingkan gerak ketimbang verbal, 3) dimainkan sekitar 10-15 menit, 4) diselingi dengan nyanyian, 4) cerita disesuaikan dengan umur anak, 5) diikuti dengan tanya jawab, dan 6) siswa diberi peluang memainkannya. Sehingga dengan menggunakan media pembelajaran tiga dimensi boneka diduga hasil belajar siswa menjadi meningkat.

\section{METODOLOGI}

Metode yang digunakan dalam penelitian ini adalah metode penelitian tindakan kelas (PTK). Penelitian ini terdiri dari III siklus dimana setiap siklusnya terdiri dari perencanaan, pelaksanaan tindakan, observasi dan refeksi. Penelitian ini dilakukan di MI Al-Ishlah Kota Bandung pada semester genap bulan Februari 2016. Dengan menyesuaikan jam pelajaran Akidah Akhlak kelas III MI Al-Ishlah. Subjek penelitian ini adalah siswa kelas III MI AlIshlah, yaitu 28 siswa yang terdiri dari 12 siswa perempuan dan 16 siswa laki-laki. Dan yang menjadi objek penelitian ini adalah penggunaan media tiga dimensi. 
Pelaksanaan PTK dilakukan dalam tiga siklus. Sebelum dilaksanakan tindakan dalam penelitian ini diawali dengan mengidentifikasi dan perumusan masalah melalui observasi awal kemudian melakukan refleksi untuk menentukan cara dan tindakan pemecahan masalah yang akan ditempuh pada siklus pertama. Hasil dari pelaksanaan pada siklus pertama akan direfleksikan untuk melakukan perbaikan pelaksanaan tindakan pada siklus kedua, dan begitu pula dengan siklus-siklus selanjutnya.

Sumber data disini terdiri dari 2 sumber, yaitu sumber data primer dan sumber data sekunder. Untuk sumber data primer, bersumber dari guru dan siswa. Sedangkan untuk sumber data sekunder, bersumber dari dokumentasi, dan arsip-arsip lainnya. Instrumen dalam penelitian ini meliputi: silabus, RPP, tes , dan observasi. Ada beberapa teknik pengumpulan data yang digunakan dalam penelitian ini, diantaranya adalah: 1) Observasi, 2) wawancara, 3) tes, dan 4) dokumentasi.

Analisis data dilakukan melalui pengolahan data serta temuan-temuan yang diperoleh selama proses penelitian berdasarkan instrumen yang digunakan dalam penelitian diantaranya sebagai berikut.

1) Menganalisis Hasil Belajar

a) Penskoran

Skor adalah hasil yang diperoleh dengan jalan menjumlahkan angka bagi setiap butir item yang dijawab benar dengan memperhitungkan bobot jawaban benarnya.

b) Nilai Akhir (NA)

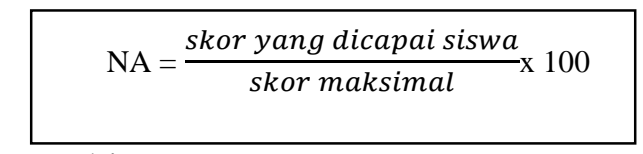

c) Menghitung rata - rata

Rata - rata nilai dihitung menggunakan rumus:

$$
X=\frac{\Sigma X}{N}
$$

Keterangan :

(Hayati, 2013, hlm. 38)

$X=$ mean/rata-rata nilai seluruh siswa

$\sum x=$ jumlah nilai seluruh siswa

$N=$ jumlah seluruh siswa

Adapun kriteria hasil belajar siswa dapat dilihat pada Tabel 1 di bawah ini.

Tabel 1. Kriteria Hasil Belajar Siswa

\begin{tabular}{|c|c|}
\hline Rentang skor & Kategori \\
\hline $85-100$ & Sangat baik \\
\hline $70-84$ & Baik \\
\hline $55-69$ & Sedang \\
\hline $40-54$ & Kurang \\
\hline$<40$ & Sangat kurang \\
\hline
\end{tabular}


d) Ketuntasan Klasikal

Untuk menghitung ketuntasan belajar secara klasikal mengacu pada pendapat Aqib yang dikutip dari jurnal (Syehma: 5) yaitu:

Presentase ketuntasan belajar $=\frac{\Sigma \text { siswa yang tuntas belajar }}{\Sigma \text { siswa }} \times 100 \%$

2) Menganalisis hasil observasi

Untuk mengetahui aktivitas guru dan aktivitas siswa selama penelitian perlu menganalisis semua kegiatan pada waktu pembelajaran. Untuk menganalisis aktivitas guru dan aktivitas siswa diperlukan pedoman untuk penilaian sebagai hasil dari analisis. Sehingga data hasil pengamatan observasi aktivitas guru dan aktivitas siswa selama pembelajaran berlangsung dengan menggunakan media tiga dimensi dapat diperoleh. Observasi yang dilakukan menggunakan teknik chechlist atau daftar isian.

Untuk menentukan dan mendapatkan nilai dapat menggunakan rumus sebagai berikut.

a) Kriteria penilaian observasi aktivitas guru

Presentase $=\frac{\text { skor yang di perolehan }}{\text { skor total }} \times 100 \%$

b) Kriteria penilaian observasi aktivitas siswa

Presentase $=\frac{\text { skor yang di perolehan }}{\text { skor total }} \times 100 \%$

\section{HASIL DAN DISKUSI}

Setelah dilakukan tindakan, diperoleh hasil penelitian sebagai berikut.

Tabel 2. Presentase Aktivitas Guru Siklus I

\begin{tabular}{|c|c|c|c|c|}
\hline \multirow{2}{*}{$\begin{array}{c}\text { Aktivitas Guru } \\
\text { Siklus I }\end{array}$} & \multicolumn{4}{|c|}{ Aktivitas Guru dalam \% } \\
\cline { 2 - 5 } & Kurang & Cukup & Baik & Sangat baik \\
\hline I & 19 & 37 & 44 & 0 \\
\hline
\end{tabular}

Adapun presentase aktivitas guru siklus I jika dibuat dalam bentuk diagram, maka seperti terlihat pada gambar 1 sebagai berikut:

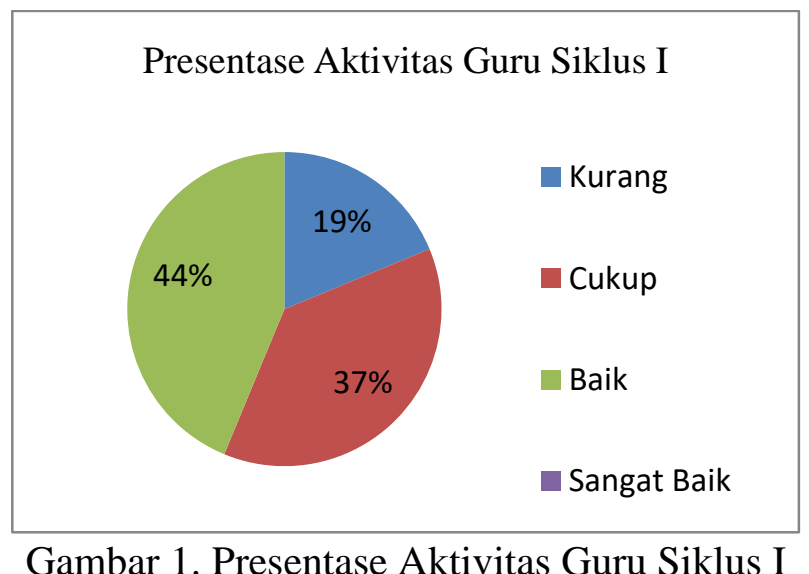

Berdasarkan Tabel 2 dan Gambar 1 menunjukan bahwa aktivitas guru selama mengikuti kegiatan pembelajaran pada siklus I dengan menggunakan media tiga dimensi 
berbentuk boneka memperoleh presentase tertinggi mencapai $44 \%$ dengan kategori baik. Meskipun ada beberapa aspek yang masih belum terlaksana dengan baik.

Tabel 3. Presentase Aktivitas Siswa Siklus I

\begin{tabular}{|c|c|c|c|c|}
\hline \multirow{2}{*}{$\begin{array}{c}\text { Aktivitas Siswa } \\
\text { Siklus I }\end{array}$} & \multicolumn{4}{|c|}{ Aktivitas Siswa dalam \% } \\
\cline { 2 - 5 } & Kurang & Cukup & Baik & Sangat baik \\
\hline I & 42 & 17 & 33 & 8 \\
\hline
\end{tabular}

Adapun presentase aktivitas siswa pada siklus I jika dibuat dalam bentuk diagram,dapat dilihat pada gambar 2 sebagai berikut.

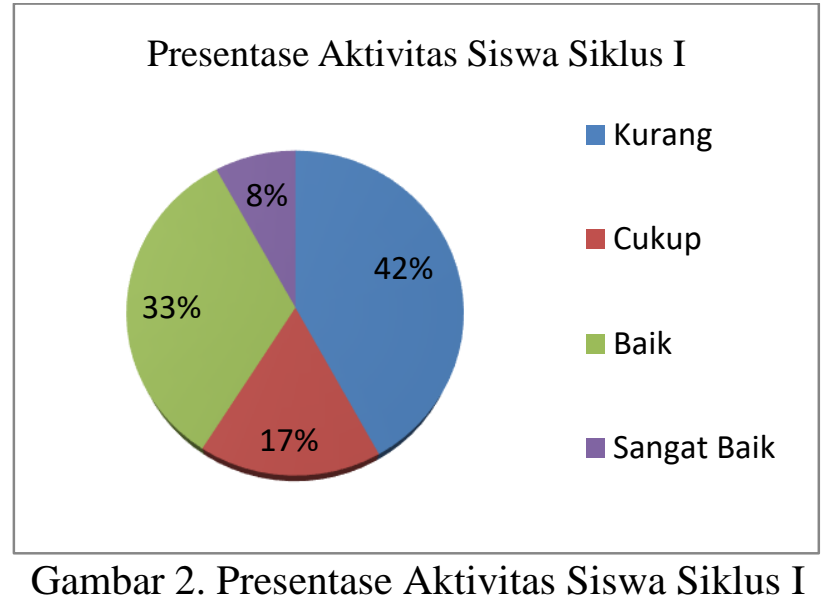

Berdasarkan Tabel 3 dan gambar 2 menunjukan bahwa aktivitas siswa selama mengikuti kegiatan pembelajaran pada siklus I dengan menggunakan media tiga dimensi berbentuk boneka memperoleh presentase tertinggi mencapai $42 \%$ dengan kategori kurang.

Tabel 4. Presentase Aktivitas Guru Siklus II

\begin{tabular}{|c|c|c|c|c|}
\hline \multirow{2}{*}{$\begin{array}{c}\text { Aktivitas Guru } \\
\text { Siklus II }\end{array}$} & \multicolumn{4}{|c|}{ Aktivitas Guru dalam \% } \\
\cline { 2 - 5 } & Kurang & Cukup & Baik & Sangat baik \\
\hline II & 0 & 6 & 69 & 25 \\
\hline
\end{tabular}

Adapun presentase aktivitas guru siklus II jika dibuat dalam bentuk diagram, maka seperti terlihat pada gambar 3 sebagai berikut.

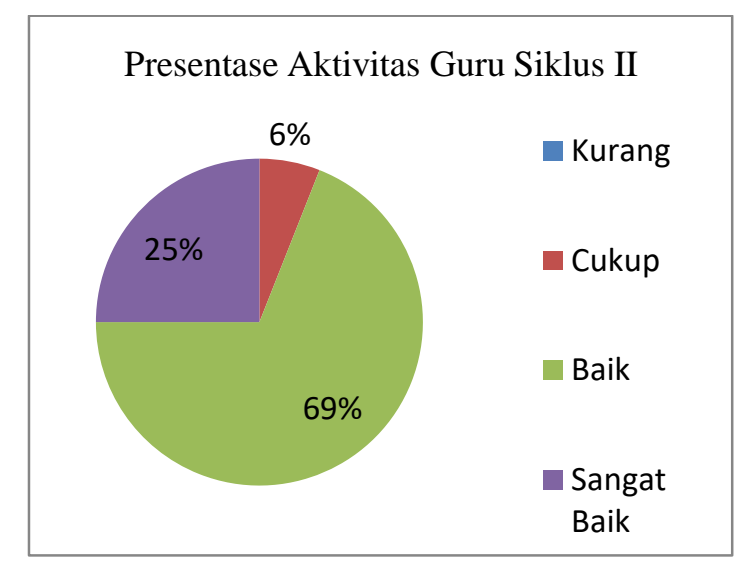

Gambar 3. Presentase Aktivitas Guru Siklus II 
Berdasarkan Tabel 4 dan Gambar 3 menunjukan bahwa aktivitas guru selama mengikuti kegiatan pembelajaran pada siklus II dengan menggunakan media tiga dimensi berbentuk boneka memperoleh presentase tertinggi mencapai $69 \%$ dengan kategori baik dengan demikian melihat dari aktivitas guru pada siklus sebelumnya siklus ke II ini mengalami peningkatan dari siklus sebelumnya.

Tabel 5. Presentase Aktivitas Siswa Siklus II

\begin{tabular}{|c|c|c|c|c|}
\hline \multirow{2}{*}{$\begin{array}{c}\text { Aktivitas Siswa } \\
\text { Siklus II }\end{array}$} & \multicolumn{4}{|c|}{ Aktivitas Siswa dalam \% } \\
\cline { 2 - 5 } & Kurang & Cukup & Baik & Sangat baik \\
\hline II & 0 & 25 & 67 & 8 \\
\hline
\end{tabular}

Adapun presentase aktivitas siswa pada siklus II jika dibuat dalam bentuk diagram, dapat dilihat pada gambar 4 sebagai berikut.

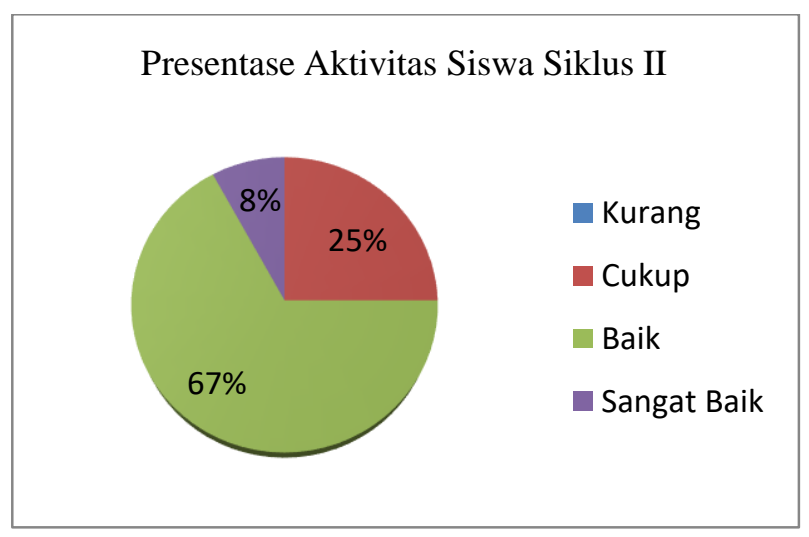

Gambar 4. Presentase Aktivitas Siswa Siklus II

Berdasarkan Tabel 5 dan Gambar 4 menunjukan bahwa aktivitas siswa selama mengikuti kegiatan pembelajaran pada siklus II dengan menggunakan media tiga dimensi berbentuk boneka memperoleh presentase tertinggi mencapai $67 \%$ dengan kategori baik.

Tabel 6. Presentase Aktivitas Guru Siklus III

\begin{tabular}{|c|c|c|c|c|}
\hline \multirow{2}{*}{$\begin{array}{c}\text { Aktivitas Guru } \\
\text { Siklus III }\end{array}$} & \multicolumn{4}{|c|}{ Aktivitas Guru dalam \% } \\
\cline { 2 - 5 } & Kurang & Cukup & Baik & Sangat Baik \\
\hline III & 0 & 0 & 19 & 81 \\
\hline
\end{tabular}

Adapun presentase aktivitas guru siklus III jika dibuat dalam bentuk diagram, maka seperti terlihat pada Gambar 5 sebagai berikut: 


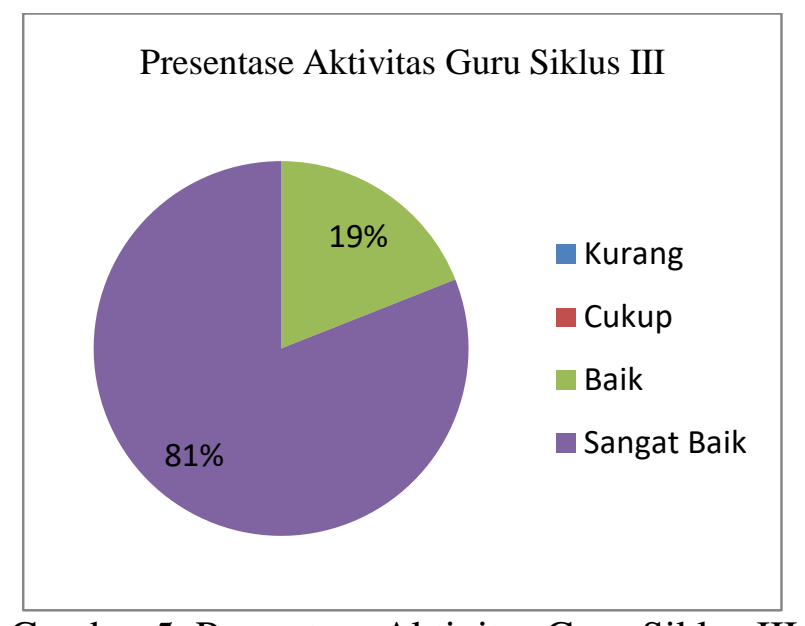

Gambar 5. Presentase Aktivitas Guru Siklus III

Berdasarkan Tabel 6 dan Gambar 5 menunjukan bahwa aktivitas guru selama mengikuti kegiatan pembelajaran pada siklus III dengan menggunakan media tiga dimensi berbentuk boneka memperoleh presentase tertinggi mencapai $81 \%$ dengan kategori sangat baik dengan demikian melihat dari aktivitas guru pada siklus sebelumnya siklus ke III ini mengalami peningkatan dari siklus-siklus sebelumnya.

Tabel 7. Presentase Aktivitas Siswa Siklus III

\begin{tabular}{|c|c|c|c|c|}
\hline \multirow{2}{*}{$\begin{array}{c}\text { Aktivitas Siswa } \\
\text { Siklus III }\end{array}$} & \multicolumn{4}{|c|}{ Aktivitas Siswa dalam \% } \\
\cline { 2 - 5 } & Kurang & Cukup & Baik & Sangat baik \\
\hline III & 0 & 0 & 33 & 67 \\
\hline
\end{tabular}

Adapun presentase aktivitas siswa pada siklus III jika dibuat dalam bentuk diagram,dapat dilihat pada Gambar 6 sebagai berikut:

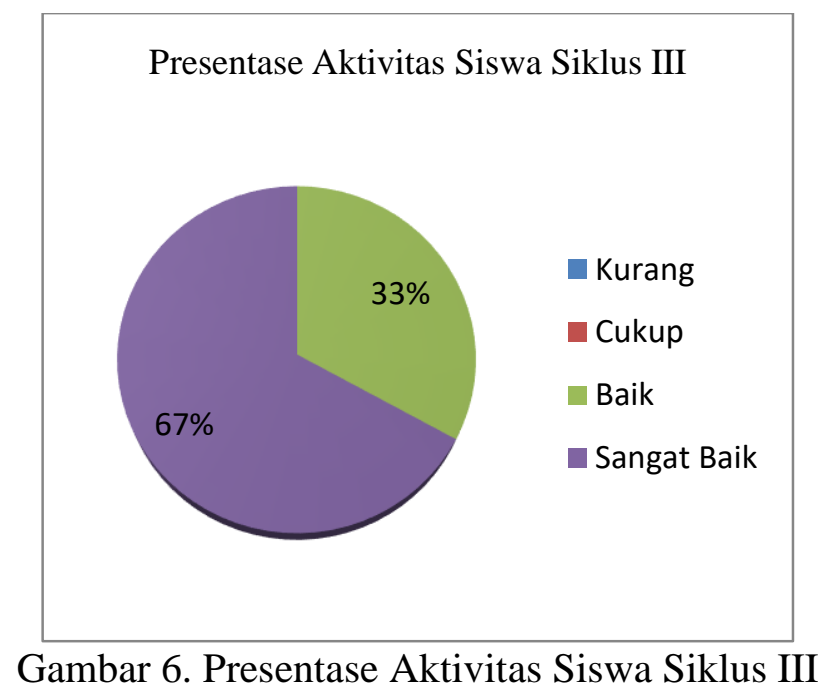

Berdasarkan Tabel 7 dan Gambar 6 menunjukan bahwa aktivitas siswa selama mengikuti kegiatan pembelajaran pada siklus III dengan menggunakan media tiga dimensi berbentuk boneka memperoleh presentase tertinggi mencapai $67 \%$ dengan kategori sangat baik. 
Tabel 8. Hasil Belajar Siswa pada Setiap Siklus

\begin{tabular}{|c|c|}
\hline Hasil Belajar & $\begin{array}{c}\text { Rata-Rata } \\
\text { Kelas }\end{array}$ \\
\hline Siklus I & 73,21 \\
\hline Siklus II & 76,60 \\
\hline Siklus III & 81,43 \\
\hline
\end{tabular}

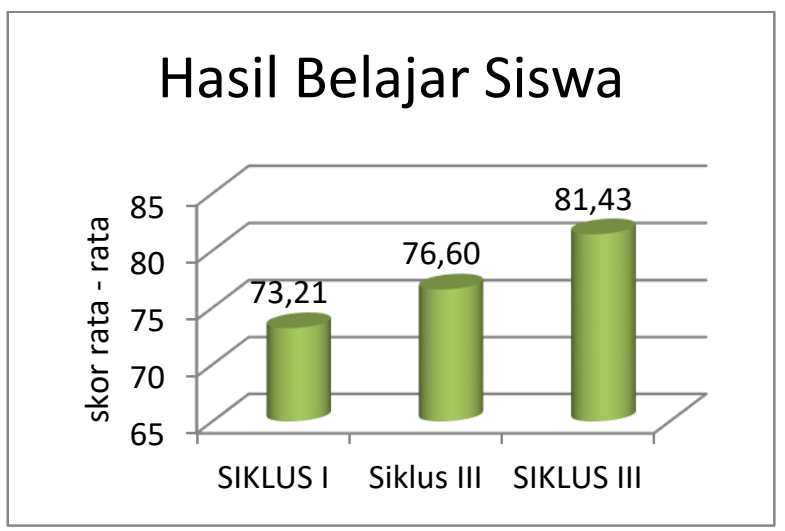

Gambar 7. Peningkatan Hasil Belajar Siswa Setiap Siklus

Berdasarkan perolehan hasil belajar siswa pada siklus I diperoleh nilai rata - rata kelas yaitu $(73,21)$, siklus II diperoleh nilai rata - rata kelas sebesar $(76,60)$, dan hasil belajar pada siklus III memperoleh nilai rata - rata kelas sebesar $(81,43)$. Berdasarkan hasil belajar siswa dalam pembelajaran Akidah Akhlak kelas III MI Al-Ishlah melalui penggunaan media boneka berhasil meningkatkan hasil belajar siswa. Hal ini ditunjukan oleh peningkatan hasil belajar siswa pada tiap siklus.

\section{KESIMPULAN}

Berdasarkan hasil penelitian yang diperoleh dapat disimpulkan sebagai berikut: 1) hasil belajar siswa sebelum menggunakan media tiga dimensi masih rendah yaitu dengan nilai rata-rata 70,03 dengan ketuntasan belajar $46 \%$. 2) proses penggunaan media tiga dimensi dalam setiap siklusnya mengalami peningkatan yaitu pada aktivitas guru siklus I dengan presentase $44 \%$, silklus II dengan presentase $69 \%$, siklus III dengan presentase $81 \%$. Sedangkan aktivitas siswa siklus I 42\%, siklus II 67\% dan siklus III 67\%. 3) hasil belajar setelah mengguankan media boneka pada setiap siklusnya mengalami peningkatan. Pada siklus I dengan rata-rata 73,21 ketuntasan belajar 54\%, kemudian pada siklus II dengan ratarata 76,60 ketuntasan belajar 82\%, dan pada siklus III mencapai rata-rata kelas yang 81,43 dengan ketuntasan belajar $89 \%$. Berdasarkan data tersebut, dapat disimpulkan bahwa pembelajaran dengan menggunakan media boneka dapat meningkatkan hasil belajar siswa kelas III MI Al-Ishlah pada mata pelajaran Akidah Akhlak. Bagi peneliti berikutnya, direkomendasikan penggunaan media boneka untuk meningkatkan aktivitas belajar siswa

\section{DAFTAR PUSTAKA}

Hayati, Tuti. (2013). Statistika Pendidikan. Bandung: CV. Insan Mandiri Ruswandi, Uus. Dkk.(2009). Landasan Pendidikan. Bandung: Insan Mandiri Sudjana, Nana. (2013). Dasar-Dasar Proses Belajar Mengajar. Bandung: Sinar Baru Algensindo Offset. 